\title{
On the Performance of a Hollow-Fiber Bioreactor for Acidolysis Catalyzed by Immobilized Lipase
}

\author{
Victor M. Balcão, F. Xavier Malcata \\ Escola Superior de Biotecnologia, Universidade Católica Portuguesa, Rua \\ Dr. António Bernardino de Almeida, P-4200 Porto, Portugal; fax: \\ 351-2-590351; e-mail: xmalcata@esb.ucp.pt
}

\begin{abstract}
The present communication describes the chemical modification of anhydrous butterfat by interesterification with oleic acid catalyzed by a lipase of Mucor javanicus. Two reactor configurations were tested, a batch-stirred tank reactor containing suspended lipase and a batch-stirred tank reactor in combination with a hollow-fiber membrane module containing adsorbed lipase. The goal of this research was to assess the advantage of using a (hydrophobic) porous support to immobilize the lipase in attempts to engineer butterfat with increased levels of unsaturated fatty acid residues (oleic acid) at the expense of medium-to-long chain saturated fatty acids (myristic and palmitic acids). Reactions were carried out at $40^{\circ} \mathrm{C}$ in the absence of solvent under controlled water activity, and were monitored by chromatographic assays for free fatty acids. The results obtained indicate that the rate of interesterification using the proposed reactor configuration is enhanced by a factor above 100 relative to that using suspended lipase, for the same protein mass basis. Although hydrolysis of butterfat occurred to some degree, the enzymatic process that uses the hollow-fiber reactor was technically superior to the stirred tank system.
\end{abstract}

Keywords: batch-stirred tank reactor; interesterification; immobilized enzyme; butterfat; membrane bioreactor; Mucor javanicus

\section{INTRODUCTION}

Lipases are enzymes that require interfacial activation for full catalytic performance, as initially reported by Sarda and Desnuelle (1958). It is now established that (1) all lipases share primary sequence homologies (Antonian, 1988), and that (2) a serine residue at the active site is protected by a flap ( $\alpha$-helical lid), which opens upon contact of the lipase with an interface (van Tilbeurg et al., 1992, 1993; Winkler et al., 1990). The requirement for an interface is crucial for lipolytic activity; even when a hydrophobic sol-

Correspondence to: F. Xavier Malacata

Contract grant sponsors: FLAD; Institut CANDIA; JNICT

Contract grant numbers: Portugal: Project Lipase-catalyzed Interesterification of butterfat with olive oil; CIENCIA BD/2091/92-1F; PRAXIS BD/5317/95; France: Project Modification de la matiére grasse par des lipases immobilisées sur un réacteur à membrane vent is employed, there are local pools of residual water within the folded structure of the lipase that provide the local interface necessary for enzyme activation.

Although use of a proper organic solvent, or emulsifier, helps overcome the problem of intimate contact between (insoluble) substrate and (soluble) enzyme in aqueous media, the practical use of lipases in such reaction systems raises technical difficulties (viz. contamination of the products with residual protein) and economic difficulties (viz. use of the enzyme for a single reactor pass). In both cases, part of the initial enzyme activity is irreversibly lost. If, by engineering its microenvironment (by attachment to a carrier) or by engineering its macroenvironment (by modification of the reaction medium and consequent precipitation in an organic solvent), the enzyme becomes an independent phase within the reaction system, then it may be retained in the reactor by mechanical means with concomitant advantages in preventing contamination of the products and extending its useful activity. Although contact of reactants with an immobilized lipase is generally improved by convection relative to molecular transport, convection is also associated with higher shear rates and/or higher times of exposure to shear (in the case of rotational or motionless agitation), or with higher surface tension and/or higher interfacial areas (in the case of bubbling agitation), both of which promote denaturing of the lipase and hence, deactivation.

The types of reactor configurations employing immobilized lipases have been reviewed elsewhere (Balcão et al., 1996a); batch-stirred tank reactors (BSTR) are most commonly employed and account for more than two thirds of reported uses. In the case of membrane reactors, the enzyme is immobilized onto the membrane, which may be either a flat sheet or a hollow-fiber design, and operated with one or two liquid phases. Among immobilization protocols, adsorption has been studied by most researchers; the ease of immobilization, the absence of expensive and toxic chemicals, the ability to retain activity and selectivity of the free lipase virtually unchanged and the ease of regeneration (based on the reversibility of the immobilization technique) may account for this observation. [It should be noted that desorption of lipase occurs in the presence of a hydropho- 
bic, polar solvent but desorption into the immobilizing aqueous buffer does not occur to a significant extent (Malcata et al., 1992a,b,c)]. Immobilization may either inhibit or enhance lipase activity. However, care should be exercized to use the same basis for comparison of lipase activity; if amount of protein is used as a basis, the selectivity of the immobilization process towards lipase when compared with other proteins in crude lipase preparations may account for some of the enhancement factors reported (Malcata et al., 1992a).

The discovery that lipases can catalyze reactions in organic media (i.e., when water is eliminated except for an essential molecular layer more or less tightly bound to the enzyme and required for its integrity) has expanded the range of lipase reactions beyond simple hydrolyses. On the other hand, a comparative assessment of the merits of a continuous hollow-fiber membrane reactor for the controlled lipolysis of butterfat with the traditional batch reactor process (Malcata and Hill, 1993) has indicated that the membrane reactor is an attractive alternative. In view of this, our research has focussed on interesterification of anhydrous butterfat brought about by a lipase immobilized by plain physical adsorption onto a bundle of hydrophobic (polypropylene) hollow-fibers where melted butterfat mixed with free oleic acid are pumped through the lumen and the shell sides. Our primary aims were production of (engineered) butterfat with a higher content of oleic acid and lower contents of lauric, myristic, and palmitic acid residues coupled with processing at a mild temperature, and assessment of the merits of the hollow fibers as physical supports for immobilization of lipase when compared with the suspended enzyme counterpart.

\section{MATERIALS AND METHODS}

\section{Materials}

\section{Enzyme}

The lipase used (Mucor javanicus) was a commercial crude powder $\left(\mathrm{M} 10^{\mathrm{TM}}\right)$ kindly supplied by Amano Pharmaceutical (Nagoya, Japan). The lyophilized lipase was stored at $-30^{\circ} \mathrm{C}$.

\section{Chemicals}

Unless otherwise indicated, all chemicals were reagentgrade or better, and were used without further purification. Diethyl ether, albumin fraction $\mathrm{V}$ (from bovine blood serum) and sodium hydroxide were obtained from Merck (Darmstadt, Germany). Fatty acid standards (> 99.9\% pure) were obtained from Sigma. Fermentation ethanol (96\% v/v) was obtained from AGA (Sacavém, Portugal). Dry nitrogen $\left(\mathrm{C}-55^{\mathrm{TM}}\right)\left(<1 \mathrm{ppm} \mathrm{H}_{2} \mathrm{O}\right.$ and $<1$ vpm $\left.\mathrm{O}_{2}\right)$ was purchased from Carburos Metalicos (Barcelone, Spain). Tap water was purified in a Milli-Q Plus 185 system (Molsheim, France) to a final conductivity of ca. $18.2 \mathrm{M} \Omega \cdot \mathrm{cm}^{-1}$.

\section{Substrates}

Salt-free, pasteurized butter was purchased from PROLEITE (Oliveira de Azeméis, Portugal) and kept in sealed plastic bags of ca. $1.5 \mathrm{~kg}$ at $-30^{\circ} \mathrm{C}$ until use. Oleic acid (min. $60 \%$ by GC assay) was obtained from Riedel-de-Haën (Seelze, Germany).

\section{Processing Equipment}

A Liqui-Cell ${ }^{\mathrm{TM}}$ laboratory module of microporous polypropylene membranes in hollow-fiber form (Celgard ${ }^{\circledR}$ X10/ 240) was purchased from Hoechst Celanese (Charlotte, $\mathrm{NC}$ ); this fiber module is $30 \mathrm{~cm}$ long (including endcaps) and $2.5 \mathrm{~cm}$ in diameter and is encased in a system with 2.5 mm-thick walls. The module consists of a bundle of ca. 2100 fibers potted in epoxy resin, which are $16 \mathrm{~cm}$ long and have a nominal internal diameter of $240 \mu \mathrm{m}$, a nominal wall thickness of $30 \mu \mathrm{m}$, a nominal porosity of $30 \%$, nominal pore dimensions of $0.050 \times 0.150 \mu \mathrm{m}$ (width $\times$ length), an effective (i.e., Brunauer-Emmet-Teller, or BET) membrane area of ca. $0.23 \mathrm{~m}^{2}$ and an effective area/volume ratio of 40 $\mathrm{cm}^{2} / \mathrm{cm}^{3}$. The void volume associated with the lumen side is $35.77 \pm 0.62 \mathrm{~cm}^{3}$, whereas the void volume associated with the shell region is $39.72 \pm 0.95 \mathrm{~cm}^{3}$ (Balcão et al., 1996b). The water bath was equipped with a mechanical agitator and a digital temperature controller (Julabo Labortechnik, Seelbach, Germany). Recirculation of fluids was achieved with high-precision metering pumps (ISMATEC MC-Z, Zürich, Switzerland). The tubing and fittings used to connect the outlet of the gear pumps to the reactor inlets and the reactor outlets to the stirred flask were made of Teflon (Cole Parmer, Chicago, IL). The hollow-fiber reactor was held in a vertical position by clamps attached to the reactor and the walls of the bath. The complete setup is depicted in Figure 1. For the batch system, a $250 \mathrm{~mL}$-volume round bottom flask inserted within a jacketed glass beaker (Schott, Duran, Germany) was used to carry out the interesterification reactions. The setup comprised a constant temperature bath equipped with a mechanical agitator and a digital temperature controller (Julabo Labortechnik), with external recirculation through the jacketed glass beaker.

\section{Analytical Equipment}

Disposable cuvettes for spectrophotometric readings were purchased from Kartell (Binasco, Italy). The HPLC equipment (MERCK, Darmstadt, Germany) used consisted of a programmable autosampler (model L-7250), a LichroCART® 250-4 C-18 reversed-phase column $(25 \mathrm{~cm} \times 4 \mathrm{~mm}$ $\times 5 \mu \mathrm{m}$ Lichrospher® 100) coupled with a pre-column cartridge (4 mm LichroCART®, Manu-CART® ' 4”), a programmable solvent delivery system with a quaternary pump (model L-7100), a programmable multiwavelength UV 


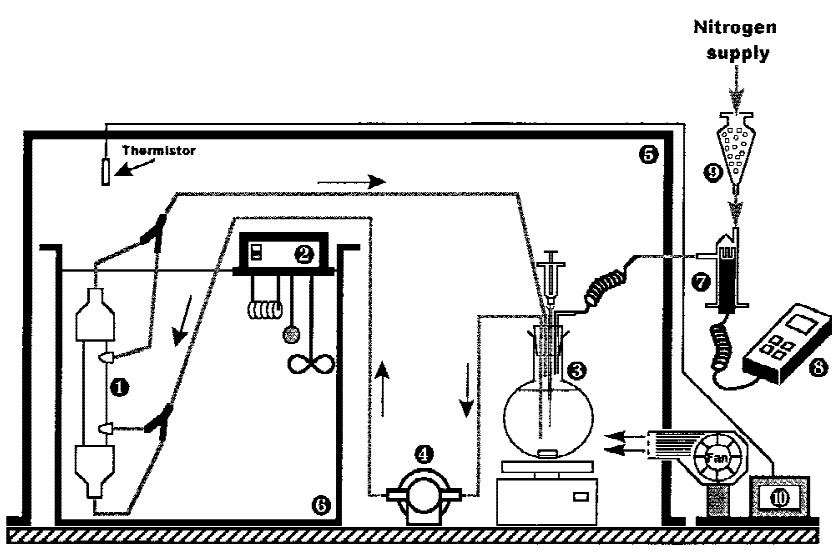

Figure 1. Experimental setup used for the lipase-catalyzed interesterification reactions of butterfat. (1 - Hollow-fiber bioreactor; (2) - Temperature controller; 3 - Well-stirred flask containing the reactant mixture; 4 - High precision gear pump, $\boldsymbol{\sigma}$ - Perspex dome with controlled air temperature; $\boldsymbol{6}$ - Water bath; $\boldsymbol{0}$ - Moisture probe; $\boldsymbol{8}$ - Thermohygrometer; $\boldsymbol{\Theta}$ - Ampoule containing silica gel; and (ID - Blower/Electronic control.

spectrophotometer (model L-7400), an interface (model D7000) and a software package for system control and data acquisition (model D-7000 Chromatographic Data Station Software) from MERCK Instruments (San Jose, CA). KarlFischer titration was carried out with a $684 \mathrm{KF}$ Coulometer (Metröhm, Herisau, Switzerland).

\section{Experimental Procedures}

\section{Preparation of Anhydrous Butterfat}

The procedure for pretreatment of butter prior to interesterification was an adaptation of the procedure described by Kalo et al. (1990). Details of the modified procedure are described elsewhere (Balcão and Malcata, 1998a; Balcão et al., 1998).

\section{Protein Assays}

The amount of protein adsorbed onto the fibers of the hollow-fiber reactor was measured as the difference between the protein content of the lipase buffer solutions before and after the immobilization procedure. The (spectrophotometric) assays for protein followed the Coomassie Brilliant Blue G-250 (Robyt and White, 1990) method modified by Balcão et al. (1996b).

\section{Immobilization of Lipase in the Hollow Fibers}

Due to the hydrophobic character of the hollow fibers, the reactor was prewet by rinsing with a series of liquids prior to each immobilization procedure: absolute ethanol for ca. $15 \mathrm{~min}$ (to completely fill the pores of the fibers and remove air bubbles), water for ca. $15 \mathrm{~min}$ (to strip ethanol away until it could not be detected by smell in the effluent stream) and Mcllvaine buffer (Dawson et al., 1969) for ca. $10 \mathrm{~min}$ (to establish the microenvironmental $\mathrm{pH}$ ). In each experi- ment, $250 \mathrm{~mL}$ of lipase solution [1.692 $\mathrm{g}$ of crude lipase powder per L of McIlvaine buffer (Balcão et al., 1996b)] was poured into a beaker and recirculated for ca. $10 \mathrm{~h}$ through both the lumen and the shell sides of the fibers in the module at a flow rate of ca. $112 \mathrm{~mL} / \mathrm{h}$. After each interesterification reaction, and before the next reaction, the hollow-fiber module was rinsed with diethyl ether/ethanol $(50 \%, \mathrm{v} / \mathrm{v}$ ) for ca. $20 \mathrm{~min}$ (to remove butterfat and adsorbed protein from the hollow fibers) and water for ca. $15 \mathrm{~min}$ (in order to strip diethyl ether/ethanol away from the membrane pores); from then on, the procedure was as described.

\section{Performance of Interesterification in BSTR}

All butterfat modification reactions in the batch stirred tank reactor (BSTR) were carried out at $40^{\circ} \mathrm{C}$ using the processing configuration schematically depicted in Figure 1 (without the hollow-fiber module and so with its inlet directly connected to its outlet). For each reaction, $200 \mathrm{~mL}$ of reacting mixture (butterfat with added oleic acid) was poured into the round bottom flask. Thermal equilibration of the mixture $\left(40^{\circ} \mathrm{C}\right)$ was ca. $10 \mathrm{~min}$; after this period, a known amount of crude $\mathrm{M} 10^{\mathrm{TM}}$ lipase powder (ca. $425 \mathrm{mg}$ ) was added to the flask and the reaction was allowed to proceed for $150 \mathrm{~h}$. The headspace above the reaction mixture was anhydrous nitrogen at flow rate of ca. $2 \mathrm{~L} / \mathrm{h}$. The reaction medium was continuously agitated via magnetic stirring at ca. $750 \mathrm{rpm}$.

\section{Performance of Interesterification in HFMR}

All butterfat modification reactions encompassing the hollow-fiber membrane reactor (HFMR) were carried out at $40^{\circ} \mathrm{C}$ using the processing configuration schematically depicted in Figure 1. After lipase immobilization and immediately before the start of each experiment, the following sequence of procedures was followed: The reactor was placed upside down and the reactant mixture (melted dry butterfat with a given percentage $(\mathrm{v} / \mathrm{v})$ of oleic acid) was pumped through the reactor (so as to completely replace the aqueous buffer in the lumen- and shell-sides of the fibers), the reactor was inverted to its regular operating position (inlet streams at the bottom) and the reactant mixture was circulated for an extra 2 min (before starting the stopwatch). The whole system was kept under a perspex dome with the air temperature controlled at $40 \pm 3^{\circ} \mathrm{C}$ (to prevent solidification of the butterfat in the tubing). Recirculation of the reacting melted mixture through the reactor was accomplished with two metering pumps. Volumes of reactant mixture, ranging from $350 \mathrm{~mL}$ to $375 \mathrm{~mL}$, were recirculated for ca. $150 \mathrm{~h}$ through the lumen side and shell side of the hollow fibers at flow rates of ca. $35 \mathrm{~mL} / \mathrm{h}$ and ca. $31 \mathrm{~mL} / \mathrm{h}$, respectively, to obtain similar space times in both sides. Throughout each experiment, dried nitrogen was bubbled through the recirculating fat mixture in the beaker (to assist in water and oxygen removal and thus prevent hydrolysis and oxidation of butterfat). 


\section{Assay for Free Fatty Acids}

In either processing situation, aliquots of butterfat were withdrawn at regular time intervals from the flask containing the recirculating mixture and assayed for free fatty acids by HPLC upon derivatization by $p$-bromophenacylbromide, according to procedures described elsewhere (Balcão and Malcata, 1998a,b; Balcão et al., 1998).

\section{Assay for Water}

The moisture content of butterfat was determined by coulometry. Melted mixtures were weighed in a warm syringe, injected promptly into the Karl-Fischer's reaction vessel and titrated with in situ generated iodine until the equivalence point was reached.

\section{EXPERIMENTAL RESULTS}

The (dried) nitrogen bubbling through the reactant mixture had an average relative humidity of ca. $0.54 \%$ throughout the entire reaction. This corresponds to an average value of 0.0054 for the water activity of the butterfat feedstock. Protein content of the crude lipase powder was ca. $9.74 \%$ (w/w) (BSA equivalent). The amount of protein adsorbed onto the hollow fibers was $6.54 \pm 0.82 \mu \mathrm{g} / \mathrm{cm}^{2}$ membrane, which corresponds to an immobilization yield of $59.7 \pm 5.7$ $\%$ of the protein in the supernatant solution.

\section{Free Fatty Acid Profiling}

The results pertaining to the concentrations of free fatty acids (FFA) in butterfat undergoing lipase-catalyzed interesterification are plotted in Figure 2 for all reaction conditions studied. As can be observed, the concentrations of all saturated fatty acid residues in free form increase slightly during the entire reaction timeframe. In general, smaller additions of free oleic acid to butterfat prior to starting the lipase-catalyzed reaction caused higher releases of saturated fatty acid moieties while, at the same time, prevented incorporation of oleic acid into triacylglycerols of butterfat. On the other hand, as expected, higher additions of free oleic acid to butterfat were successful in promoting lipasecatalyzed incorporation of this monounsaturated fatty acid into the triacylglycerols of butterfat; this trend was always noticed irrespective of the temperature of the reaction over the range $35-40^{\circ} \mathrm{C}$. The increase in concentration of some, and the decrease in concentration of other, fatty acids in free form was expected to occur during acidolysis, whereas the increase of the total concentration of free fatty acids produced by hydrolysis is in agreement with the net reduction of the water content in the reaction medium. At $35^{\circ} \mathrm{C}$, the free fatty acids that displayed the highest percentage increase were stearic, palmitic, and butyric acids (as concluded from the data depicted in Figs. 2c, d). On the other hand, at $40^{\circ} \mathrm{C}$, lauric, myristic, and palmitic acids had the highest increase by the end of the reaction (see Figs. 2a, b). Because lauric, myristic, and palmitic acid moieties have been implicated in hypercholesterolemic effects following ingestion of saturated fats (Ney, 1991; Vessby, 1994), lipase-catalyzed reaction at $40^{\circ} \mathrm{C}$ would seem at first glance to be more suitable for enzyme-mediated modification of butterfat. In general, fatty acids with acyl carbon chains greater than 10 carbon atoms showed the highest net increase, which may reflect an acyl specificity of the fungal lipase used.

When using a well-stirred beaker containing the reactant mixture and the dissolved crude lipase powder to perform the reaction, changes in the concentration of free oleic acid were low (see Figs. 2e, f) and only slight incorporation of oleic acid was observed. However, when the enzyme was immobilized in the external hollow-fiber membrane connected in series to the beaker (see Fig. 1), the concentration of free oleic acid in the reaction medium was reduced by $23.5 \%$ (see Fig. 2c) at $35^{\circ} \mathrm{C}$ and $13.6 \%$ (see Fig. 2a) at $40^{\circ} \mathrm{C}$ relative to the initial concentrations (calculated as final amount in reactant mixture minus initial amount in reactant mixture normalized to the latter).

The total concentration of FFAs in the reaction medium and the ratio of free saturated (S) fatty acids to free unsaturated (U) fatty acids are depicted in Figure 3 for all reaction conditions tested. The total concentration of free fatty acids displayed a virtually linear trend with addition of higher initial amounts of free oleic acid (see Figs. 3a, c, e, f), which certainly corresponds to the initial part of the progress reaction curve of a typical equilibrium-limited chemical process. However, when adding smaller amounts of free oleic acid prior to performing the reaction, a hyperbolic-shaped trend could be perceived (see Figs. 3b, d). Regarding the ratio of concentrations of $\mathrm{S}$ to $\mathrm{U}$ free fatty acids, hyperbolic trends could be noticed for all situations employing the hollow-fiber module (see Figures 3a, b, c, d) and a linear trend in situations employing the BSTR (see Figs. 3e, f).

\section{Lipase Adsorption}

One model that has been successfully used (Malcata et al., 1992a) to fit protein adsorption data is the Langmuir adsorption isotherm. This model can be written as $\mathrm{C}_{\text {protein,ads }}=\mathrm{C}_{\text {protein,ads,max }} \cdot \mathrm{K}_{\text {protein }} \cdot \mathrm{C}_{\text {protein,free }} /$ $\left\{1+K_{\text {protein }} \cdot \mathrm{C}_{\text {protein,free }}\right\}$, where $\mathrm{C}_{\text {protein,ads }}$ denotes the amount of protein removed from the supernatant solution per unit area of membrane, $\mathrm{C}_{\text {protein,free }}$ represents the protein concentration in the bulk of the supernatant solution by the end of the adsorption experiment, $\mathrm{K}_{\text {protein }}$ is an adsorption equilibrium constant and $\mathrm{C}_{\text {protein,ads,max }}$ is the saturation coverage (or maximum amount) of protein that can ever be adsorbed per unit area of membrane. Experimental data obtained during adsorption of lipase onto the hydrophobic hollow fibers is displayed in Figure 4, together with the fit provided by the Langmuir isotherm using nonlinear regression. The best estimates and associated standard error for the parameters were $\mathrm{C}_{\text {protein,ads, } \max }=8.37 \pm 0.93 \mu \mathrm{g} / \mathrm{cm}^{2}$ and $K_{\text {protein }}=(1.17 \pm 0.60) \times 10^{-1} \mathrm{~cm}^{3} / \mu \mathrm{g}$. 

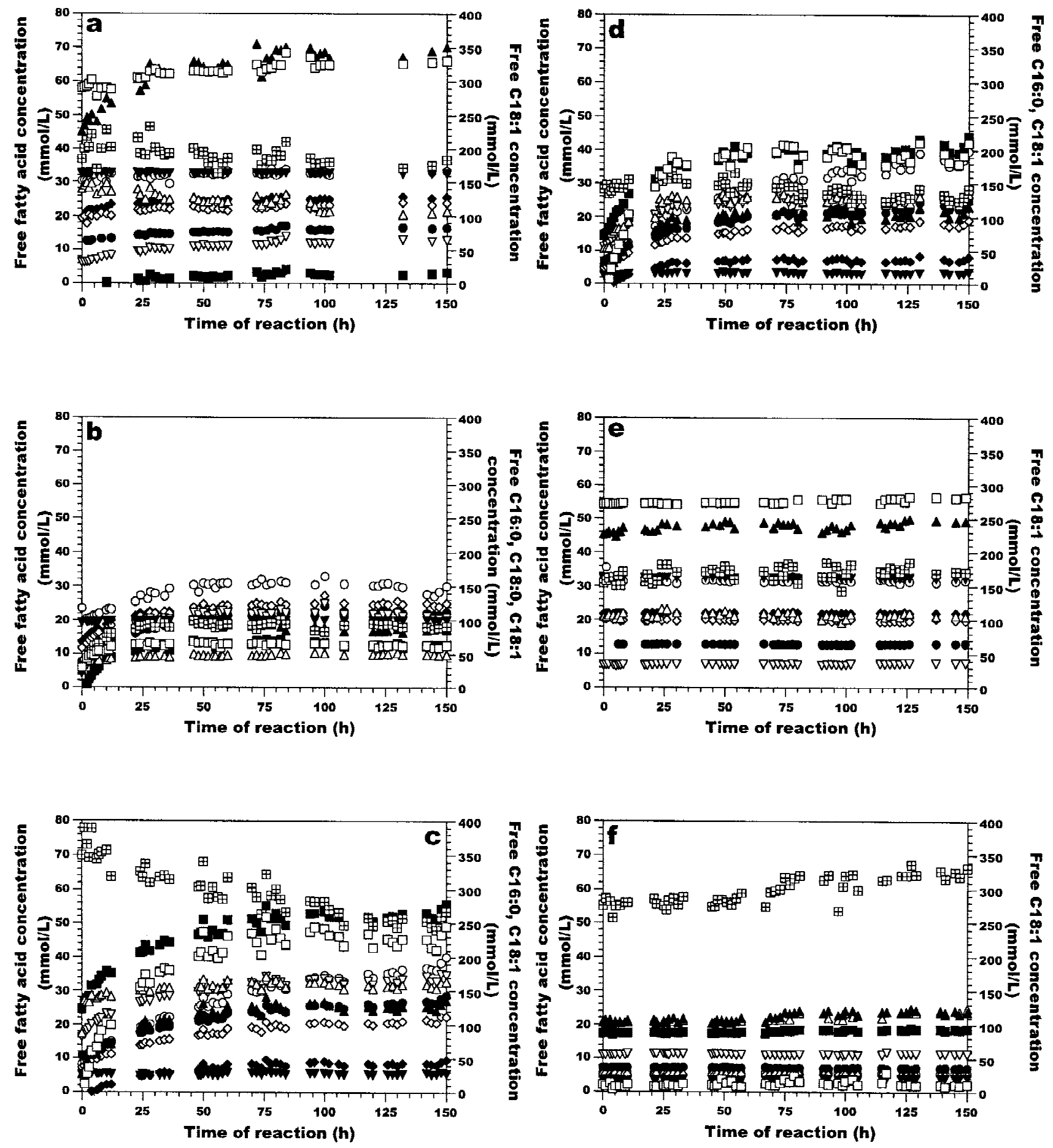

Figure 2. Evolution of the concentrations of free butyric $(\bigcirc)$, caproic $(\bullet)$, caprylic $(\diamond)$, capric $(\diamond)$, lauric $(\nabla)$, linolenic $(\nabla)$, myristic $(\square)$, linoleic $(\triangle)$, palmitic $(\mathbf{\Delta})$, oleic $(\boxplus)$ and stearic $(\square)$ acids in butterfat undergoing lipase-catalyzed reaction under the following experimental situations: (a) addition of $20 \% \mathrm{C} 18: 1$ and performance of reaction in BSTR + HFMR at $40^{\circ} \mathrm{C}$; (b) addition of $1 \% \mathrm{C} 18: 1$ and performance of reaction in BSTR + HFMR at $40^{\circ} \mathrm{C}$; (c) addition of $20 \% \mathrm{C} 18: 1$ and performance of reaction in BSTR + HFMR at $35^{\circ} \mathrm{C}$; (d) addition of $7 \% \mathrm{C} 18: 1$ and performance of reaction in BSTR + HFMR at $35^{\circ} \mathrm{C}$; (e) addition of $10 \% \mathrm{C} 18: 1$ and performance of reaction in BSTR at $40^{\circ} \mathrm{C}$; and (f) addition of $20 \% \mathrm{C} 18: 1$ and performance of reaction in BSTR at $40^{\circ} \mathrm{C}$.

\section{Fatty Acid Residue Exchange Rates}

The average rate of release (+) or incorporation (-) of each individual fatty acid moiety over the first $24 \mathrm{~h}$ of reaction is displayed in Figure 5 for both processing configurations selected. As can be seen in Figure 5a, when performing lipase-catalyzed reaction in a well-stirred system with free lipase, the rate of incorporation of oleic acid into the triacylglycerols of butterfat was only minimal even at high ratios of free oleic acid; on the other hand, even at small ratios of addition of free oleic acid, a high average rate of release of palmitic and oleic acids could be noticed. When using a hollow-fiber membrane module to immobilize lipase and 

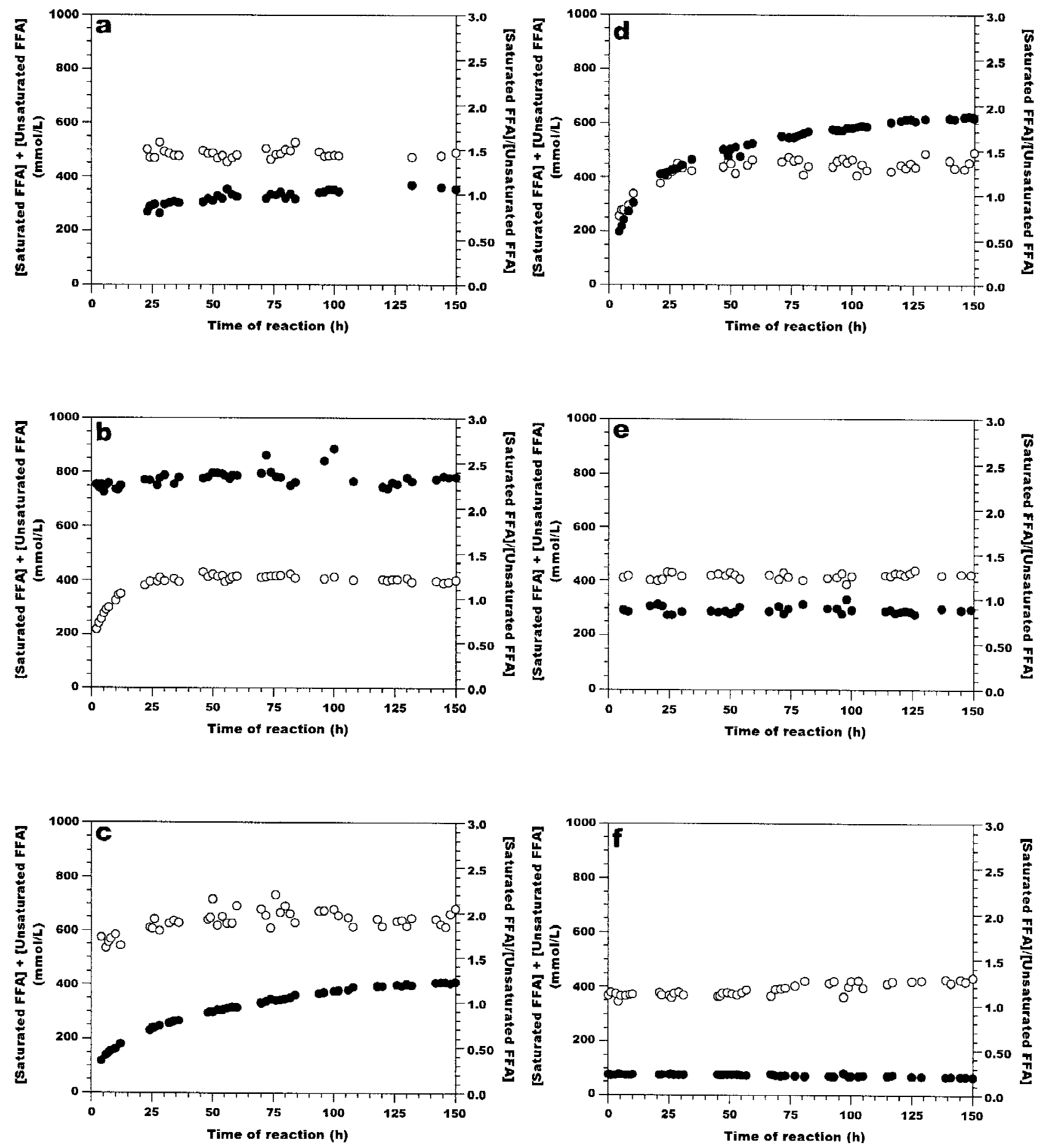

Figure 3. Evolution of the total concentrations of free fatty acids $(\bigcirc)$ and of the ratio of concentrations of saturated to unsaturated free fatty acids $(\bullet)$ throughout reaction time under the following experimental situations: (a) addition of $20 \% \mathrm{C} 18: 1$ and performance of reaction in BSTR + HFMR at $40^{\circ} \mathrm{C}$; (b) addition of $1 \% \mathrm{C} 18: 1$ and performance of reaction in BSTR + HFMR at $40^{\circ} \mathrm{C}$; (c) addition of $20 \% \mathrm{C} 18: 1$ and performance of reaction in BSTR + HFMR at $35^{\circ} \mathrm{C}$; (d) addition of $7 \% \mathrm{C} 18: 1$ and performance of reaction in BSTR + HFMR at $35^{\circ} \mathrm{C}$; (e) addition of $10 \% \mathrm{C} 18: 1$ and performance of reaction in BSTR at $40^{\circ} \mathrm{C}$; and (f) addition of $20 \% \mathrm{C} 18: 1$ and performance of reaction in BSTR at $40^{\circ} \mathrm{C}$.

perform reaction outside the stirred system, higher rates of release of saturated fatty acid moieties were obtained, even when oleic acid was added at low levels (see Fig. 5b). As shown in Figure 5b, higher levels of free oleic acid to butterfat prior to recirculating the mixture through the hollowfiber membrane module resulted in higher incorporation of this monounsaturated acid into the triacylglycerols of butterfat.

\section{DISCUSSION}

In the present research, two solvent-free systems were compared with regard to lipase-mediated modification of but- 


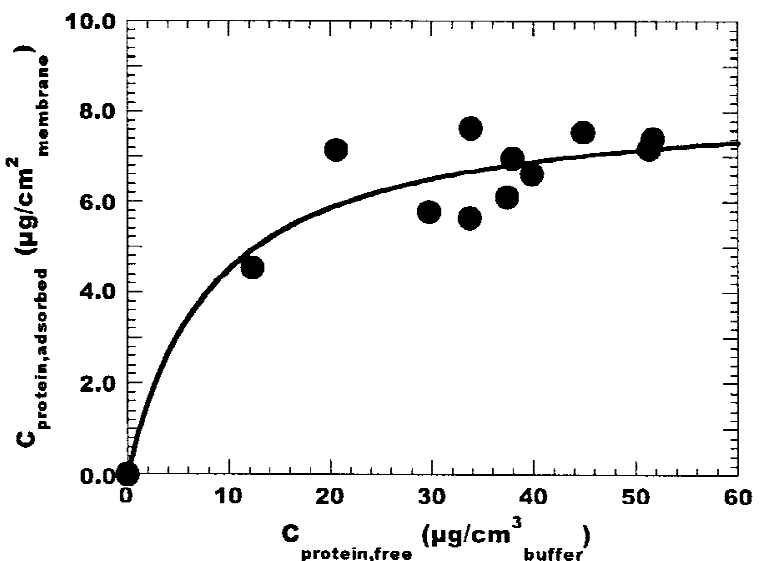

Figure 4. Adsorption isotherm of protein in the crude lipase preparation at $40^{\circ} \mathrm{C}$ : experimental data $(\bullet)$ and theoretical fit using the Langmuir isotherm (-).

terfat via interesterification with oleic acid: (1) a beaker which held well-stirred reactants and a commercial lipase in free form, vs. (2) a similar beaker which held reactants, but where the reaction itself was effected in a bundle of hollow fibers containing immobilized lipase, i.e., reaction performed outside the beaker. The goal was to compare the alternative configurations to perform lipase-mediated acidolysis with oleic acid, at the same protein mass basis, and hence, assess the advantages of using hollow fibers as lipase carrier relative to using the lipase in free form.

The selection of the two temperatures to perform lipasecatalyzed reaction was a compromise between preventing solidification of butterfat inside the teflon tubing and the gear pumps (so temperatures below $35^{\circ} \mathrm{C}$ could not be used), and reducing thermal deactivation of lipase (so temperatures above $40^{\circ} \mathrm{C}$ were not attractive for long-term experiments, as experimentally double checked). A number of lipase-catalyzed reactions studied in the past were carried out in emulsion systems; however, there is an impetus to avoid use of emulsifiers because, in industrial processes (Balcão et al., 1996a), (1) emulsions are sometimes difficult to break, and (2) replacing oil/bulk water interfaces by bound water/oil interfaces leads to lower deactivation rates of lipase.

Operation of a reactor in a continuous fashion in the absence of air minimizes the chance for lipid oxidation or growth of microorganisms, which leads to a further advantage in terms of food handling. Furthermore, displacement of the reactant phase occurs by flow tangential to the membrane rather than by percolation through the pores of the membrane, with consequent advantages in terms of low pressure drops and low shear rates. The lipase is also not likely to be removed from the support because it is immobilized by adsorption rather than by mechanical containment (Malcata et al., 1992b; Pronk et al., 1988) and the solvent-free reaction system employed is of a hydrophobic, apolar nature. As claimed by Lee and Choo (1989), lipases are not (apparently) sensitive to shear stress, so it is not likely that mechanical deactivation played a role in our studies.

Experiments were done at relatively mild temperatures and under an inert atmosphere, so thermal, or oxidative, damage to the lipase can also be considered negligible. In addition, our experiments used pure substrates in the presence of lipase (i.e., an apolar hydrophobic medium), so deactivation of lipase is expected to be delayed because bulk water was absent (except for bound water needed for maintaining the integrity of the lipase's globular structure). Finally, it should be stressed that the local interface necessary for lipase activation may have been provided by the local pools of water retained within the folded structure of the enzyme in the vicinity of the active site.

Adsorption protein isotherms are characterized by finite initial slopes; additionally, they reach well-defined plateaus at rather dilute concentrations (Malcata et al., 1992a). Hence, for data obtained at a single temperature, as in the present study, two parameters are sufficient to provide an accurate description of the affinity of a lipase (and other contaminating proteins) for the polypropylene surface: a binding constant $\left(\mathrm{K}_{\text {protein }}\right)$ and a constant, which provides a measure of monolayer coverage of the surface $\left(\mathrm{C}_{\text {protein,ads,max }}\right)$ (Norde et al., 1987; Young et al., 1988). The Langmuir model for the adsorption isotherm is consistent with this behavior, and was accordingly used to correlate our experimental data. The value obtained for $\mathrm{K}_{\text {protein }}, 3.05$ $\times 10^{6} \mathrm{dm}^{3} / \mathrm{mol}$, using the nominal lipase molecular weight of 26.1 kDa obtained by SDS-PAGE (Balcão et al., 1988c; Taipa et al., 1992), is of the same order of magnitude as the ones reported by Malcata et al. (1992a) for adsorption of lipase from Aspergillus niger onto a similar support. The surface area associated with each adsorbed protein molecule, $\mathrm{A}_{\text {ads }}$ (calculated from $\mathrm{C}_{\text {protein,ads,max }}=\mathrm{MW}_{\text {protein }}$ / $\left(\mathrm{A}_{\mathrm{ads}} \cdot \mathrm{N}_{\mathrm{A}}\right)$, where $M \mathrm{~W}_{\text {protein }}$ is the molecular weight of the adsorbed protein and $\mathrm{N}_{\mathrm{A}}$ is Avogadro's number), was estimated as $51.8 \AA^{2} /$ molecule. This calculated value for $\mathrm{A}_{\text {ads }}$ is larger than that reported by Malcata et al. (1992a), and this discrepancy may be explained, in part, by differences in the surface areas of the two membranes employed because they have different pore structure and porosity. The area associated with each adsorbed molecule plays a major role in determining the saturation concentration corresponding to monolayer coverage (Malcata et al., 1992a); the value obtained for $A_{\text {ads }}$, together with the value obtained for $\mathrm{C}_{\text {protein,ads,max }}$, is evidence of the high protein loading capacity of the membranes used, which in fact is ca. 2.3 times higher than that reported elsewhere (Malcata et al., 1992a) for a similar reactor encasing a smaller number of individual fibers. It may be claimed that immobilization of lipase should better have been expressed based on enzyme units instead of protein units because good protein adsorption may be associated with a poor activity of immobilized lipase. However, Malcata et al. (1992a) have reported that, for a similar type of membrane, the process of adsorption of crude lipase preparations was, in fact, also a purification step because the lipase molecules have more affinity for the 

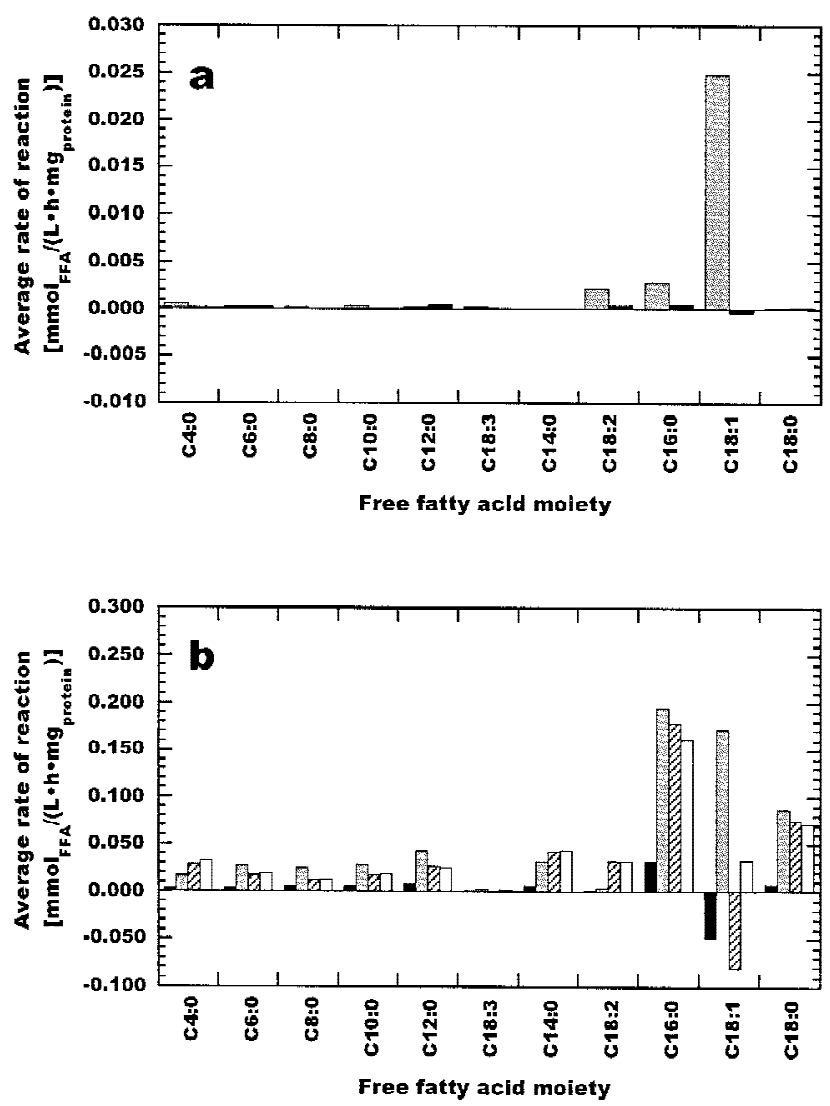

Figure 5. Average rate of release (+) or incorporation (-) of each individual fatty acid moiety over the first $24 \mathrm{~h}$ of reaction in every experimental condition tested, viz. (a) BSTR with insolubilized lipase after addition of $10 \%(\square)$ or $20 \%$ (口) C18:1 and performance of reaction at $40^{\circ} \mathrm{C}$, and (b) BSTR + HFMR after addition of $1 \%(\square)$ or $20 \%$ ( $\square$ ) C18:1 and performance of reaction at $40^{\circ} \mathrm{C}$, and addition of $7 \%$ ( $\square$ ) or $20 \%$ (质) C18:1 and performance of reaction at $35^{\circ} \mathrm{C}$.

hydrophobic polypropylene surface than other contaminant proteins. On the other hand, the lipolytic activity removed from the supernatant, and not the lipolytic activity of the lipase actually adsorbed, should be fit to the Langmuir isotherm because hyperactivation of lipase can (as observed in our case) occur upon immobilization. In either situation, literature data on adsorption consistently use protein basis rather than enzyme unit basis, and so our approach was more appropriate in view of comparison with literature.

The results obtained in this research (i.e., above 100-fold increase in reaction rate for the same amount of protein used, thus ruling out effects arising from the loading capacity of the enzyme carrier relative to the free enzyme counterpart) are in agreement with the reported hyperactivation of Mucor javanicus lipase upon adsorption onto octylagarose gels, which are hydrophobic supports with large specific surface area (Guisán et al., 1997), and postulated hypotheses that lipases recognize such well-defined hydrophobic supports as solid interfaces and may thus become adsorbed via the external surfaces of the big hydrophobic pocket around the active center of their open and activated structure (Guisán et al., 1997) without involving the active site itself. Therefore, the active conformation of the experimental lipase used might have been reached and locked when physical adsorption onto the hydrophobic matrix occurred (Giorno et al., 1995; Reetz, 1997; Yamane et al., 1986), thus explaining the enhancement in activity which was actually noticed; positive effects of higher water activity cannot be claimed in our case, owing to the hydrophobic nature of the membrane. Alternatively, because the adsorption process may also be considered as a purification step when crude enzyme mixtures containing lipase are used (Malcata et al., 1992a,b,c), as claimed before, selective immobilization of lipase relative to the overall protein inventory of the crude commercial lipase powder may also partially account for the putative hyperactivation. The reproducibility of the immobilization process via physical adsorption is apparent in the standard deviation of the amount of protein adsorbed onto the hollow fibers in ten independent immobilization trials, viz. $8.37 \pm 0.93 \mu \mathrm{g} / \mathrm{cm}^{2}$ (see Fig. 4).

When using a hollow-fiber membrane module to immobilize lipase and perform reaction outside the well-stirred system, higher rates of release of saturated fatty acid moieties were observed (see Fig. 5b) over the first $24 \mathrm{~h}$ of reaction. As seen in Figure 5b, higher levels of free oleic acid to butterfat resulted in increased incorporation of this monounsaturated fatty acid into the triacylglycerols of butterfat. Remarkably, the one-order of magnitude difference between the scales of plots depicted as Figures $5 \mathrm{~b}$ and a further supports the postulated hyperactivation of lipase upon adsorption onto a hydrophobic polymer surface. Our observations are in agreement with results presented by Guisán et al. (1997), who reported a 12-fold increase in the hydrolytic activity of Mucor javanicus lipase after adsorption onto octyl agarose gels. Furthermore, the character of the immediate vicinity of the immobilized lipase is changed from macroaqueous (during the initial step involving adsorption of lipase on the membrane) to microaqueous (during operation of the reactor); water molecules are known to have a strong influence on the conformation of lipases (Malcata et al., 1992b).

Inspection of Figures $2 \mathrm{a}$ and $\mathrm{b}$ indicates that, when performing the reaction at $40^{\circ} \mathrm{C}$, higher releases of such hypercholesterolemic fatty acid residues as lauric, myristic, and palmitic acids (Balcão and Malcata, 1998d) were attained than at $35^{\circ} \mathrm{C}$ (see Figs. 2c, d): Short-chain fatty acids were marginally affected at $40^{\circ} \mathrm{C}$. However, the reaction at $35^{\circ} \mathrm{C}$ (see Figs. 2c, d) reversed these trends, viz. short-chain fatty acids were released in higher amounts than the medium-chain fatty acids. Oleic acid was, over the first $24 \mathrm{~h}$ of reaction, incorporated to a higher extent at $35^{\circ} \mathrm{C}$ for higher initial addition in free form [viz., $11.2 \times 10^{-2} \mu \mathrm{mol} /$ $\left(\mathrm{h} \cdot \mu \mathrm{g}_{\text {protein }} \cdot \mathrm{kg}_{\text {butterfat }}\right.$ ) (see Fig. 2a)] than at $40^{\circ} \mathrm{C}$ [viz., 6.74 $\times 10^{-2} \mu \mathrm{mol} /\left(\mathrm{h} \cdot \mu \mathrm{g}_{\text {protein }} \cdot \mathrm{kg}_{\text {butterfat }}\right.$ ) (see Fig. $2 \mathrm{c}$ )], but the amounts of short-chain fatty acids released at $35^{\circ} \mathrm{C}$ are higher than at $40^{\circ} \mathrm{C}$. Because these acids contribute to the fine, unique flavor of butterfat, it is expected that processing at $35^{\circ} \mathrm{C}$ will be more detrimental to said flavor. Accord- 
ingly, a compromise must be made between the two temperatures in lipase-mediated interesterification of butterfat if the aim is to produce butterfat with higher nutritional appeal.

Inspection of Figures 2e and $\mathrm{f}$ indicates that no significant qualitative and quantitative changes in the fatty acid residue population occurred when the reaction was carried out with suspended lipase, regardless of the amount of oleic acid initially added. On the other hand, inspection of Figure $3 \mathrm{e}$ indicates that the total concentration of free fatty acids remains virtually constant throughout the reaction at lower initial additions of free oleic acid, and that the ratio of saturated to unsaturated free fatty acids increases only slightly in the same timeframe (at a rate of $2.57 \times 10^{-4} \mathrm{~h}^{-1}$ ), which denotes a minor incorporation of free oleic acid into the triacylglycerols of butterfat. At higher levels (see Fig. 3f), however, the total concentration of FFAs increases (although) slightly throughout reaction time. The first $24 \mathrm{~h}$ of reaction were, in fact, crucial as higher addition levels of free oleic acid led to a higher (yet marginal) incorporation of oleic acid residues into the TAGs of butterfat, viz. $5.89 \times$ $10^{-4} \mu \mathrm{mol} /\left(\mathrm{h} \cdot \mu \mathrm{g}_{\text {protein }} \cdot \mathrm{kg}_{\text {butterfat }}\right)$ (see Figs. $2 \mathrm{f}$ and $5 \mathrm{a}$ ); however, afterwards net hydrolysis was observed with oleic acid being released in free form into the medium (see Fig. 2f).

Inspection of Figure $3 \mathrm{a}$ shows that when performing lipase-catalyzed reaction at $40^{\circ} \mathrm{C}$ and higher initial additions of free oleic acid, a preferential release of saturated (S) fatty acids relative to unsaturated (U) fatty acids occurred over the whole timeframe of reaction, and this (almost) linear increase in the $[\mathrm{S}] /[\mathrm{U}]$ ratio with time (at the rate of $1.89 \times$ $10^{-3} \mathrm{~h}^{-1}$ ) implies a pseudo-zero order (gradual) interesterification of butterfat glycerides with added oleic acid. These results are in agreement with those reported elsewhere (Balcão and Malcata, 1998b; Balcão et al., 1998). Inspection of Figure $3 \mathrm{a}$ also shows that the total concentration of free fatty acids in the reaction medium increases slightly over the whole reaction timeframe, thus indicating that net (although slight) hydrolysis has occurred. Such slight degree of hydrolysis agrees with the low water activity of the reaction medium (although it may be claimed that the water activity of butterfat should have been standardized via pumping the whole feedstock through the HFMR, it should be noted that the water activity was controlled in the BSTR at all times via bubbling of dry nitrogen, as apparent in Figure 1). At lower additions of free oleic acid (see Fig. 3b), hydrolysis seemed to be favored (as apparent from the hyperbolic-shape of the evolution of total free fatty acid concentration throughout reaction time) relative to the incorporation of oleic acid, as shown by the slope of the S/U curve $\left(5.30 \times 10^{-4} \mathrm{~h}^{-1}\right)$, thus denoting only a marginal reduction of this monounsaturated fatty acid moiety in free form. Inspection of Figures $3 \mathrm{c}$ and $\mathrm{d}$ indicates that when performing lipase-catalyzed reaction at $35^{\circ} \mathrm{C}$, a preferential release of saturated (S) fatty acids existed relative to their unsaturated (U) counterparts over the first $24 \mathrm{~h}$ of reaction, but from then on this trend was somewhat interrupted, and a leveling off was observed.

\section{CONCLUSIONS}

The results obtained in this research effort indicate that a heterogeneous biocatalysis system encompassing a bundle of hollow-fiber membranes where a $s n$-1,3-specific lipase is immobilized with the aim of effecting acidolysis of butterfat with oleic acid is a viable alternative to the traditional system encompassing pure substrate with precipitated lipase, and the commercial lipase from Mucor javanicus is apparently hyperactivated upon adsorption relative to its suspended counterpart. When performing reaction in a hollowfiber bioreactor containing adsorbed lipase, the interesterification rate between butterfat and added free oleic acid, referred to the same amount of protein, is enhanced by a factor of ca. 115 relative to the interesterification rate using suspended lipase. A limited specificity towards short-chain fatty acid residues in butterfat triacylglycerols was also observed at $40^{\circ} \mathrm{C}$ (thus allowing preservation of its delicate aroma profile), and interesterification of butterfat with oleic acid resulted mainly in exchange of myristic, palmitic, and stearic acid residues of the former with the latter acid.

The lipase used was a gift from Amano Pharmaceutical.

\section{References}

Antonian, E. 1988. Recent advances in the purification, characterization and structure determination of lipases. Lipids 23: 1101-1106.

Balcão, V. M., Paiva, A. L., Malcata, F. X. 1996a. Bioreactors with immobilized lipases: State-of-the-art. Enzyme Microb. Technol. 18: 392-416.

Balcão, V. M., Vieira, M. C., Malcata, F. X. 1996b. Adsorption of protein from several commercial lipase preparations onto a hollow-fiber membrane module. Biotechnol. Prog. 12: 164-172.

Balcão, V. M., Malcata, F. X. 1998a. Interesterification and acidolysis of butterfat with oleic acid by Mucor javanicus lipase: Changes in the pool of fatty acid residues. Enzyme Microb. Technol., in press.

Balcão, V. M., Malcata, F. X. 1998b. Lipase-catalyzed modification of butterfat via acidolysis with oleic acid. J. Molecular Catalysis B: Enzymatic 3: 161-169.

Balcão, V. M., Oliveira, T. A., Malcata, F. X. 1998c. Stability of a commercial lipase from Mucor javanicus: Kinetic modeling of $\mathrm{pH} \cdot$ and temperature dependencies. Biocatal. Biotransf., in press.

Balcão, V. M., Malcata, F. X. 1998d. Modification of milkfat via catalysis effected by lipases: Invited review. Biotechnol. Adv., in press.

Balcão, V. M., Kemppinen, A., Malcata, F. X., Kalo, P. J. 1998. Lipasecatalyzed acidolysis of butterfat with oleic acid: Characterization of process and product. Enzyme Microb. Technol., submitted.

Dawson, R. M. C., Elliott, W. H., Elliott, D. C., Jones, K. M. 1969. Data for biochemical research, p. 427. Oxford Science Publications, Oxford, UK.

Giorno, L., Molinari, R., Drioli, E., Bianchi, D., Cesti, P. 1995. Performance of a biphasic organic/aqueous hollow fiber reactor using immobilized lipase. J. Chem. Tech. Biotechnol. 64: 345-352.

Guisán, J. M., Bastida, A., Sabuquillo, P., Armisen, P., FernándezLafuente, R., Huguet, J. 1997. Interfacial adsorption of lipases on strongly hydrophobic solid surfaces: hyperactivation and improved stereospecificity, p. 36. In: Proceedings of the international meeting lipases and lipids: Structure, specificity and applications in biocatalysis, Como, Italy.

Kalo, P., Huotari, H., Antila, M. 1990. Pseudomonas fluorescens lipasecatalysed interesterification of butterfat in the absence of a solvent. Milchwiss. 45: 281-285. 
Lee, Y.-K., Choo, C.-L. 1989. The kinetics and mechanism of shear inactivation of lipase from Candida cylindracea. Biotechnol. Bioeng. 33: $183-190$

Malcata, F. X., Garcia, H. S., Hill, C. G., Amundson, C. H. 1992a. Hydrolysis of butteroil by immobilized lipase using a hollow-fiber reactor: Part I. Lipase adsorption studies. Biotechnol. Bioeng. 39: 647-657.

Malcata, F. X., Hill, C. G., Amundson, C. H. 1992b. Hydrolysis of butteroil by immobilized lipase using a hollow-fiber reactor: Part II. Uniresponse kinetic studies. Biotechnol. Bioeng. 39: 984-1001.

Malcata, F. X., Hill, C. G., Amundson, C. H. 1992c. Hydrolysis of butteroil by immobilized lipase using a hollow-fiber reactor: Part IV. Effects of temperature. Biotechnol. Bioeng. 39: 1097-1111.

Malcata, F. X., Hill, C. G. 1993. Hydrolysis of butteroil by immobilized lipase in a hollow fiber membrane reactor: Optimization and economic considerations, pp. 107-122. In: R. Paterson (ed.), Third international conference on effective membrane processes-New perspectives. Mechanical Engineering Publications, UK.

Ney, D. M. 1991. Potential for enhancing the nutritional properties of milkfat. J. Dairy Sci. 74: 4002-4012.

Norde, W., Fraaye, J. G. E. M., Lyklema, J. 1987. Protein adsorption at solid-liquid interfaces: A colloid-chemical approach. In: J. L. Brash and T. A. Horbett (eds.), Proteins at interfaces-Physicochemical and biochemical studies. American Chemical Society, Washington, DC.

Pronk, W., Kerkhof, P. J. A. M., van Helden, C., van't Riet, K. 1988. The hydrolysis of triglycerides by immobilised lipase in a hydrophilic membrane reactor. Biotechnol. Bioeng. 32: 512-518.
Reetz, M. T. 1997. Entrapment of lipases in hydrophobic sol-gel materials for use in organic chemistry, p. 30. In: Proceedings of the international meeting lipases and lipids: Structure, specificity and applications in Biocatalysis, Como, Italy.

Robyt, J. F., White, B. J. 1990. Biochemical techniques-Theory and practice. Waveland, IL.

Sarda, L., Desnuelle, P. 1958. Action de la lipase pancréatique sur les esters en émulsion. Biochim. Biophys. Acta 30: 513-521.

Taipa, M. A., Aires-Barros, M. R., Cabral, J. M. S. 1992. Purification of lipases-Minireview. J. Biotechnol. 26: 111-142.

van Tilbeurg, H., Sarda, L., Verger, R., Cambillau, C. 1992. Structure of the pancreatic lipase-procolipase complex. Nature 359: 159-162.

van Tilbeurg, H., Egloff, M. P., Martinez, C., Rugani, N., Verger, R., Cambillau, C. 1993. Interfacial activation of the lipase-procolipase complex by mixed micelles revealed by X-ray crystallography. Nature 362: 814-820.

Vessby, B. 1994. Effects of long-chain fatty acids on health in man-Impacts of new findings on nutritional recommendations. INFORM 5: $182-185$.

Winkler, F. K., D'Arcy, A., Hunziker, W. 1990. Structure of human pancreatic lipase. Nature 343: 771-774.

Yamane, T., Hoq, M. M., Shimizu, S. 1986. Kinetics of continuous hydrolysis of olive oil by lipase in microporous hydrophobic membrane reactor. J. Jpn. Oil Chem. Soc. (YUKAGAKU): 10-17.

Young, B. R., Pitt, W. G., Cooper, S. L. 1988. Protein adsorption on polymeric biomaterials. J. Coll. Interf. Sci. 124: 28. 